\title{
Analisis Pengaruh Keamanan, Kesehatan dan Keselamatan Kerja terhadap Kinerja Pegawai Kantor Penanggulangan Bencana Kabupaten Majene
}

\section{Analysis of the Effect of Occupational Safety and Safety on Employee Performance at the Majene District Disaster Management Office}

\author{
Safriansyah $^{1 *}$, Muh. Rezky Naim ${ }^{2 *}$ \\ ${ }^{1}$ Universitas Terbuka Unit Program Belajar Jarak Jauh (UPBJJ) Majene \\ ${ }^{2}$ Sekolah Tinggi Ilmu Ekonomi (STIE) YAPMAN Majene
}

\begin{abstract}
ABSTRAK
Penelitian ini dilakukan untuk meningkatan kemampuan mutu Keamanan, Kesehatan Kerja dan Keselamatan Kerja terhadap Kinerja Pegawai pada Kantor Organisasi Perangkat Daerah (OPD) Penanggulangan Bencana Kabupaten Majene Provinsi Sulawesi Barat. Tujuan Penelitian ini bertujuan untuk menganalisis pengaruh Keamanan Kerja terhadap Kinerja pegawai pada Kantor OPD Penanggulangan Bencanda Kabupaten Majene Provinsi Sulawesi Barat, menganalisis pengaruh Keselamatan Kerja terhadap Kinerja pegawai pada Kantor OPD Penanggulangan Bencana Kabupaten Majene Provinsi Sulawesi Barat dan menguraikan pengaruh Keselamatan Kerja terhadap Kinerja pegawai pada Kantor OPD Penanggulangan Bencana Kabupaten Majene Provinsi Sulawesi Barat, serta menganalisis yang manakah paling peubah independen dominan berpengaruh terhadap peubah dependen. Data yang digunakan adalah data primer dan sekunder. Populasi penelitian adalah seluruh pegawai/staf pada Kantor OPD Penaggulangan Bencana Kabupaten Majene Provinsi Sulawesi Barat. Penelitian ini adalah sebanyak 30 orang pegawai dengan teknik sampling. Pengumpulan data dilakukan melalui kusioner, dan dokumentasi. Metode Analisis data menggunakan analisis statistik deskriptif, dan regresi linear berganda menggunakan program SPSS 24.00. Hasil penelitian menunjukkan secara simultaan (bersama-sama) menunjukkan perbedaan Keamanan Kerja sebesar 30,0\%, Kesehatan Kerja sebesar 43\% dibandingkan dengan Keselamatan Kerja 88,5\% atau di atas dari 0,05 ini membuktikan ketiga tersebut berpengaruh terhadap Kinerja Pegawai pada Kantor OPD Penanggulangan Bencana Kabupaten Majene Provinsi Sulawesi Barat. Hal ini mengindikasikan ada pengaruh bersama-sama Keamanan Kerja, Kesehatan Kerja dan Keselamatan Kerja terhadap Kinerja Pegawai sehingga tujuan penelitian ini melalui analisis, deskripsi dan penguraian pengaruh dari ketiga variabel dapat sesuai dengan hasil analisis khususnya pada Kantor OPD Penanggulangan Bencana Kabupaten Majene Provinsi Sulawesi Barat.
\end{abstract}

Kata kunci: keselamatan, kesehatan dan keamanan kerja, kinerja pegawai

\section{ABSTRACT}

This research was conducted to improve ability quality security, occupational health and safety against the performance of an employe at the Office (OPD) disaster relief District of West Sulawesi Province of Majene. The purpose of this research was aimed to: analyse the influence of job security against the performance of an employe at the Office (OPD) Counter measure Bencana Regency of West Sulawesi Province of Majene, analyzing the influence of Safety against the performance of employees on Office (OPD) Counter measure Bencana Regency of West Sulawesi Province of Majene and outlines the influence of Safety against the performance of an employee at the Office (OPD) disaster relief District of West Sulawesi Province of Majene, as well as analyze that most independent variables which are the dominant influence on the dependent variables. The data used are the primary and secondary data. The population of the research was the entire corporate staff in Office Penanggulangan (OPD) Disaster Countries Majene West Sulawesi Province. The research is as many as 30 employees with sampling techniques. Data collection was done through kusioner, and documentation. Methods of data analysis using descriptive

\footnotetext{
*) Korespondensi:

Jl. Sultan Hasanuddin No. 2 Majene. Majene 91412; email: safri.ut@gmail.com
} 
statistical analysis, and multiple linear regression using SPSS program 24.00. The results showed in simultaan (together) shows the difference job security of $30.0 \%$, occupational health of $43 \%$ compared with $88.5 \%$ Safety or on top of 0.05 is proving the influential third on performance Clerk at the Office of District disaster management (OPD) Majene West Sulawesi province. This indicates there is influence together job security, occupational health and safety against the performance of the Employee so that the purpose of this research through analysis, description and a description of the three variables can influence can match with the results of the analysis particularly in the Office of the District disaster management (OPD) Majene West Sulawesi province.

Key words: employee performance, health and security of work, safety

\section{PENDAHULUAN}

Keamanan, Kesehatan dan Keselamatan Kerja (K3) merupakan salah satu aspek perlindungan tenaga kerja yang diatur dalam UU Nomor 13 Tahun 2003. Dengan menerapkan teknologi pengendalian keselamatan dan kesehatan kerja, diharapkan tenaga kerja akan mencapai ketahanan fisik, daya kerja, dan tingkat kesehatan yang tinggi. Di samping itu dapat diharapkan untuk menciptakan kenyamanan kerja dan keselamatan kerja yang tinggi. Jadi, unsur yang ada dalam kesehatan dan keselamatan kerja tidak terpaku pada faktor fisik, tetapi juga mental, emosional dan psikologi.

Keamanan kerja adalah suatu usaha untuk menjaga dan melindungi pekerja dan fasilitas/aset yang dimiliki, baik yang berada di dalam Kantor maupun yang berada di luar lingkungan Kantor. Upaya memberikan jaminan keamanan kerja tidak hanya diperuntukkan bagi tenaga kerja yang bekerja di dalam lingkungan Kantor, tetapi juga bagi tenaga kerja yang bekerja di lapangan, misalnya: Pegawai bank yang bertugas mengambil atau mengantarkan uang ke suatu tempat perlu mendapat pengawalan yang ketat untuk mengantisipasi tindak kejahatan.

Kesehatan kerja merupakan suatu hal penting dan perlu diperhatikan oleh pihak pengusaha. Dengan adanya program kesehatan yang baik akan menguntungkan para pegawai secara material, karena pegawai akan lebih jarang absen, bekerja dengan lingkungan yang lebih menyenangkan, sehingga secara keseluruhan pegawai akan mampu bekerja lebih lama. "Istilah kesehatan mengacu pada kondisi psikologis fisik dan psikologis pekerja yang merupakan hasil dari lingkungan yang diberikan oleh kantor. Jika suatu kantor melakukan pengukuran keamanan dan kesehatan yang efektif, semakin sedikit pegawai yang mengalami dampak penyakit jangka pendek atau jangka panjang akibat bekerja di kantor tersebut."
Keselamatan kerja adalah keselamatan yang bertalian dengan mesin, pesawat, alat kerja, bahan dan proses pengolahannya, landasan tempat kerja dan lingkungannya serta cara-cara melakukan pekerjaan. Keselamatan kerja bersasaran segala tempat kerja, baik didarat, didalam tanah, dipermukaan air, didalam air, maupun diudara. Tempat-tempat demikian tersebar segenap kegiatan ekonomi, seperti pertanian, industri, pertambangan, perhubungan, pekerjaan umum, jasa dan lain-lain. Salah satu aspek penting sasaran keselamatan kerja mengingat risiko bahayanya adalah penerapan teknologi, terutama teknologi yang lebih maju dan mutakhir. Keselamatan kerja adalah tugas semua orang yang bekerja. Keselamatan kerja adalah dari, oleh, untuk setiap tenaga kerja, serta orang lainnya dan juga masyarakat pada umumnya. Keamanan kerja adalah unsur-unsur penunjang yang mendukung terciptanya suasana kerja yang aman, baik berupa material maupun nonmaterial.

Menurut Wirawan (2009) kinerja adalah keluaran yang dihasilkan oleh fungsi atau indikator-indikator suatu pekerjaan atau suatu profesi dalam waktu tertentu. Selanjutnya As'ad (2001) berpendapat bahwa kinerja adalah suatu kesuksesan seseorang dalam melaksanakan suatu pekerjaan. Hasibuan (2001), kinerja adalah suatu hasil kerja yang dicapai seseorang dalam melaksanakan tugas yang dibebankan kepadanya yang didasarkan atas kecakapan, pengalaman dan kesungguhan, serta waktu.

Kinerja pegawai adalah hasil kerja secara mutu dan kuantitas yang dicapai oleh seorang pegawai dalam melaksanakan tugasnya sesuai dengan tanggungjawab yang diberikan kepadanya. Untul itu dapat didefinisikan kinerja dan hasil kerja pegawai, baik mutu maupun kuantitas yang dicapai oleh pegawai dalam periode tertentu sesuai tanggung jawab yang diberikan.

Pengelolaan sistem jaminan keselamatan dan kesehatan kerja dalam pendekatan modern lebih maju dengan diperhatikan dan diikutinya 
sistem jaminan K3 sebagai bagian dari manajemen kantor. Hal ini disadari karena dari data kecelakaan yang terjadi juga mengakibatkan kerugian yang cukup besar. Dengan mengakibatkan banyaknya risiko yang diperoleh kantor, maka mulailah diterapkan sistem jaminan K3 yang menerapkan pola preventif terhadap kecelakaan yang terjadi. Dalam sistem ini menuntut tidak hanya keterlibatan pihak manajemen, tetapi juga komitmen dari pihak luar yang terkait. Pada kenyataannya walaupun kondisi K3 di Kantor OPD Penanggulangan Bencana Kabupaten Majene Provinsi Sulawesi Barat masih sangat minim namun kinerja pegawai pada Kantor ini sangat tinggi. Teori dan kondisi di lapangan yang sangat bertolak belakang maka dilakukan penelitian berjudul "Pengaruh Keamanan, Kesehatan dan Keselamatan Kerja terhadap Kinerja Pegawai pada Kantor OPD Penanggulangan Bencana Kabupaten Majene Provinsi Sulawesi Barat"

\section{METODE PENELITIAN}

Penelitian ini dilaksanakan di Kantor OPD Penanggulangan Bencana Kabupaten Majene yang terletak di Jalan Poros Majene Mamuju Deteng-Deteng Kecamatan Banggae Kabupaten Majene Provinsi Sulawesi.

Populasi dalam penelitian ini adalah seluruh pegawai yang ada di Kantor (OPD) Penanggulangan Bencana Kabupaten Majene. Sampel dalam penelitian ini tidak digunakan teknik sampling, karena sampel yang diteliti adalah keseluruhan dari populasi yang ada atau disebut dengan sensus. Karena keterbatasan waktu dan biaya sehingga sampel dari penelitian ini sejumlah 30 orang pada Kantor (OPD) Penanggulangan Bencana Kabupaten Majene.

\section{Uji Validitas}

Uji validitas dilakuan dengan membandingkan nilai $r$ hitung dengan $r$ tabel untuk tingkat $<5$ persen dari degree of freedom $(\mathrm{df})=\mathrm{n}-2,(\mathrm{n}$ adalah jumlah. Jika $\mathrm{r}$ hitung $>\mathrm{r}$ tabel, maka pertanyaan atau indikator tersebut dinyatakan valid, demikian sebaliknya bila $r$ hitung $<\mathrm{r}$ tabel maka pertanyaan indikator tersebut dinyatakan tidak valid (Ghozali, 2005).

\section{Uji Reliabilitas}

Uji reliabilitas merupakan alat untuk mengukur suatu kuesioner sebagai indikator dari peubah atau konstruk. Suatu kuesioner dikatakan reliabel atau handal, jika jawaban seseorang terhadap pernyataan adalah konsisten atau stabil dari waktu ke waktu (Ghozali, 2005). Pengukuran reliabilitas dilakukan dengan cara one shot atau pengukuran sekali saja dengan alat bantu Statistic Packape for Social Science (SPSS) uji statistik Cronbach Alpha $(\alpha)$. Suatu konstruk atau peubah dikatakan reliabel memberikan nilai Cronbach Alpha $>0.60$ (Nunnally dalam Ghozali, 2005).

\section{Uji Asumsi Klasik}

Untuk meyakinkan bahwa persamaan garis regresi yang diperoleh adalah liniear dan dapat digunakan (valid) untuk mencari peramalan, maka akan dilakukan pengujian asumsi multikolinearitas, heteroskedastisitas dan normalitas.

\section{Uji Multikolinearitas}

Uji multikolinearitas untuk menguji apakah pada model regresi ditemukan adanya korelasi antar peubah bebas (independen). Apabila terjadi korelasi, maka dinamakan terdapat problem multikolinearitas (Ghozali, 2005). Model regresi yang baik seharusnya tidak terjadi korelasi diantara peubah bebas. Untuk mendeteksi ada atau tidaknya multikolinearitas di dalam model regresi adalah:

- Nilai $R^{2}$ yang dihasilkan oleh suatu estimasi model regresi empiris sangat tinggi, tetapi secara individual bebas banyak tidak peubah terikat (Ghozali, 2005).

- Menganalisis matrik korelasi peubah-peubah bebas. Apabila antar peubah bebas ada korelasi yang cukup tinggi (umumnya di atas 0,90$)$, maka hal ini merupakan indikasi adanya multikolinearitas (Ghozali, 2005).

- Multikolinearitas dapat dilihat dari (1) nilai tolerance dan lawannya (2) Variance Inflation Factor (VIF). Ketiga ukuran ini menunjukkan setiap peubah bebas manakah yang dijelaskan oleh peubah bebas lainnya.

- Tolerance mengukur variabilitas peubah bebas yang terpilih yang tidak dijelaskan oleh peubah bebas lainnya. Nilai tolerance yang rendah sama dengan nilai VIF yang tinggi (karena VIF $=1 /$ Tolerance). Nilai cut off umum dipakai untuk menunjukkan multikolinearitas adalah nilai tolerance $<0,10$ atau sama dengan nilai VIF $>10$ (Ghozali, 2005).

- Apabila didalam model regresi tidak ditemukan asumsi deteksi seperti di atas, maka model regresi yang digunakan dalam penelitian ini bebas dari multikolinearitas, dan demikian sebaliknya. 


\section{Uji Heteroskedastisitas}

Uji heteroskedastisitas menguji model regresi terjadi ketidaksamaan varians dari residual satu pengamatan ke pengamatan yang lain. Jika varians dari residual satu pengamatan ke pengamatan lain tetap, maka disebut homoskedastisitas dan jika varians berbeda disebut heteroskedastisitas. Model regresi yang baik adalah yang homokedastisitas atau tidak terjadi heteroskedastisitas (Ghozali, 2005).

Cara untuk mengetahui ada tidaknya heteroskedastisitas adalah melihat grafik plot antara nilai prediksi peubah terikat yaitu ZPRED dengan residualnya SRESID. Deteksi ada tidaknya heteroskedastisitas dapat dilakukan dengan melihat ada tidaknya pola tertentu pada grafik scatterplot antara SRESID dan ZPRED dimana sumbu $\mathrm{Y}$ adalah $\mathrm{Y}$ yang telah diprediksi, dan sumbu $X$ adalah residual ( $Y$ prediksi - $Y$ sesungguhnya) yang telah di studentized.

\section{Uji Normalitas}

Uji normalitas digunakan untuk menguji model regresi, ketiga peubah (bebas maupun terikat) mempunyai distribusi normal atau setidaknya mendekati normal (Ghozali, 2005). Pada prinsipnya normalitas dapat dideteksi dengan melihat penyebaran data (titik) pada sumbu diagonal dari grafik atau dengan melihat histogram dari residualnya (Ghozali, 2005) sebagai berikut:

Dimana:

$\mathrm{Y}=$ Peubah dependen (Kinerja Pegawai)

$\mathrm{A}=$ Konstanta

$\beta_{1}, \beta_{2}, \beta_{3}=$ Koefisien garis regresi

$X_{1}, X_{2}, X_{3}=$ Peubah independen (pengaruh keamananan, kesehatan dan keselamatan kerja)

e $\quad=$ error $/$ peubah pengganggu

\section{HASIL DAN PEMBAHASAN}

\section{Analisis Pengujian Instrumen Penelitian}

\section{Uji Validitas}

Hasil uji validitas dari setiap item pernyataan peubah dalam penelitian ini, dimuat pada Tabel 1. Berdasarkan hasil uji validitas yang terlihat pada Tabel 1, maka diperoleh nilai $r$ hitung dari 25 item pertanyaan berada antara 0,395 sampai dengan 0,929 , dimana nilai $\mathrm{r}$ hitung $>$ nilai $\mathrm{r}$ tabel, untuk $\mathrm{n}=30$ pada taraf $\alpha 0,05$ diperoleh $\mathrm{r}$ tabel adalah 0,306. Dengan demikian, maka dapat dinyatakan bahwa semua butir pertanyaan pada kusioner adalah valid atau mampu mengungkapkan sesuatu yang akan diukur oleh kusioner tersebut, sehingga dapat digunakan untuk analisis selanjutnya.

Tabel 1. Uji validitas instrumen penelitian

Item-Total Statistics

\begin{tabular}{|c|c|c|c|c|}
\hline \multicolumn{2}{|c|}{$\begin{array}{l}\text { Instrumen } \\
\text { Penelitian }\end{array}$} & \multirow{2}{*}{$\begin{array}{c}\text { Corrected Item-Total } \\
\text { Correlation }\end{array}$} & \multirow{2}{*}{$\begin{array}{c}\text { r Product Momentt tabel } \\
\begin{array}{c}(\mathrm{Df}=\mathbf{n}-\mathbf{2}) \text { atau }(\mathrm{Df}=\mathbf{3 0 -} \\
\mathbf{2 = 2 8} ; \boldsymbol{\alpha} \mathbf{0 , 0 5 )} \\
0,306\end{array}\end{array}$} & \multirow{2}{*}{$\begin{array}{c}\text { Ket } \\
\text { Valid }\end{array}$} \\
\hline $\mathrm{X}_{1}$ & $\mathrm{Q}_{1}$ & & & \\
\hline & $\mathrm{Q}_{2}$ & 0,673 & 0,306 & Valid \\
\hline & $\mathrm{Q}_{3}$ & 0,424 & 0,306 & Valid \\
\hline & $\mathrm{Q}_{4}$ & 0,540 & 0,306 & Valid \\
\hline & $\mathrm{Q}_{5}$ & 0,712 & 0,306 & Valid \\
\hline \multirow[t]{5}{*}{$x_{2}$} & $\mathrm{Q}_{6}$ & 0.926 & 0,306 & Valid \\
\hline & $\mathrm{Q}_{7}$ & 0.929 & 0,306 & Valid \\
\hline & $\mathrm{Q}_{8}$ & 0.924 & 0,306 & Valid \\
\hline & $\mathrm{Q}_{9}$ & 0.924 & 0,306 & Valid \\
\hline & $\mathrm{Q}_{10}$ & 0.924 & 0,306 & Valid \\
\hline \multirow[t]{5}{*}{$X_{3}$} & $\mathrm{Q}_{11}$ & 0,778 & 0,306 & Valid \\
\hline & $\mathrm{Q}_{12}$ & 0,682 & 0,306 & Valid \\
\hline & $\mathrm{Q}_{13}$ & 0,611 & 0,306 & Valid \\
\hline & $\mathrm{Q}_{14}$ & 0,395 & 0,306 & Valid \\
\hline & $\mathrm{Q}_{15}$ & 0,546 & 0,306 & Valid \\
\hline
\end{tabular}




\section{Uji Reabilitas}

Hasil uji reliabilitas dan setiap item pernyataan peubah yang digunakan dalam penelitian ini, pada Tabel 2. Hasil analisis uji reliabilitas menunjukkan nilai Cronbach's alpha ( $\mathrm{r}$ hitung) dari item pernyataan 0,847 sampai 0,923, dimana $r$ hitung $>$ nilai $r$ tabel $(0,361)$. Hal ini diartikan setiap butir pernyataan dari peubah yang digunakan dalam penelitian ini reliabel.

\section{Uji Asumsi Klasik \\ Uji Normalitas}

Hasil pada Gambar grafik Normal P Plot terlihat bahwa titik-titik menyebar disekitar garis diagonal dan penyebarannya mengikuti arah garis diagonal. Dari ketiga grafik dapat disimpulkan model regresi memenuhi asumsi normalitas.

Berdasarkan hasil pengujian grafik normal probability plot, tampak bahwa titik-titik menyebar di sekitar garis diagonal, dan penyebarannya mengikuti arus garis diagonal. Pengujian distribusi data dengan metode grafis ini menunjukkan hasil bahwa model regresi layak dipakai karena telah memenuhi asumsi normalitas.

\section{Hasil Pengujian Hipotesis}

Pengujian terhadap hasil pengujian hipotesis yang diperoleh dilakukan pengujian secara serempak dengan analisis regresi linear berganda.

\section{Uji Analisis Regresi Berganda}

Hasil pengujian Uji Analisis Regresi Linear Berganda dapat dilihat pada Tabel 3.

Pengolahan data melalui persamaan regresi berganda dengan Program Statistic Packape for Social Science (SPSS) 24.00, maka formulasi penelitian ini sebagai berikut:

$$
\mathrm{Y}=3,337+0,300 \mathrm{X}_{1}+0,434 \mathrm{X}_{2}+0,885 \mathrm{X}_{3}
$$

Dari hasil persamaan regresi linear berganda tersebut, maka dapat diberikan penjelasan berikut:

Tabel 2. Uji reabilitas instrumen penelitian

\begin{tabular}{lccc} 
& \multicolumn{4}{c}{ Item-Total Statistics } \\
Instrumen Penelitian & $\begin{array}{c}\text { r Product } \\
\text { Momentt tabel } \\
(\mathrm{Df}=\mathrm{n}-2) \text { atau }(\mathrm{Df}=30- \\
2=28 ; \alpha 0,05)\end{array}$ & $\begin{array}{c}\text { Cronbach's Alpha } \\
\text { if Item Deleted }\end{array}$ & Ket \\
\hline Keamanan Kerja $\left(\mathrm{X}_{1}\right)$ & 0,306 & 0,923 & Reliabel \\
Keselamatan Kerja $\left(\mathrm{X}_{2}\right)$ & 0,306 & 0,929 & Reliabel \\
Keselamatan Kerja $\left(\mathrm{X}_{3}\right)$ & 0,306 & 0,855 & Reliabel \\
Kinerja Pegawai $(\mathrm{Y})$ & 0,306 & 0,847 & Reliabel \\
\hline
\end{tabular}

Normal P-P Plot of Regression Standardized Residual

Dependent Variable: Kinerja Pegawai Y1

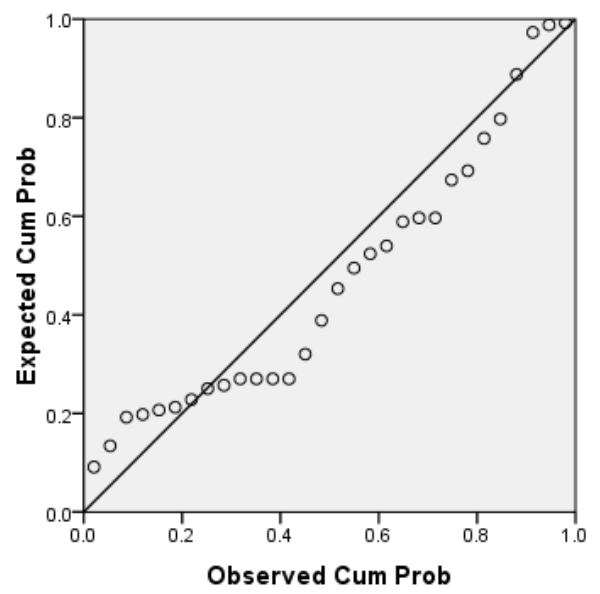

Dependent Variable: Kinerja Pegawai Y1

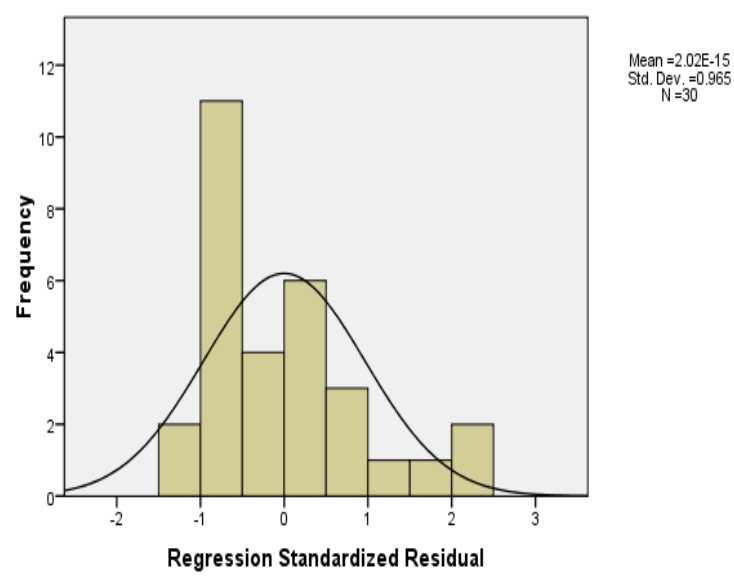

Gambar 1. Grafik normal P Plot 
Tabel 3. Regresi Linear Berganda

\begin{tabular}{lccccc}
\multicolumn{7}{c}{ Coefficients $^{\mathrm{a}}$} \\
Model & \multicolumn{2}{c}{$\begin{array}{l}\text { Unstandardized } \\
\text { Coefficients }\end{array}$} & $\begin{array}{c}\text { Standardized } \\
\text { Coefficients }\end{array}$ & $\mathbf{T}$ & Sig. \\
& $\mathbf{B}$ & Std. Error & Beta & & \\
\hline (Constant) & $\mathbf{3 . 3 3 7}$ & 2.445 & & 1.365 & .184 \\
Keamanan Kerja $\left(\mathrm{X}_{1}\right)$ & $\mathbf{0 . 3 0 0}$ & 0.155 & .256 & 2.060 & .049 \\
Kesehatan Kerja $\left(\mathrm{X}_{2}\right)$ & $\mathbf{0 . 4 3 4}$ & .321 & .402 & 1.350 & .195 \\
Keselamatan Kerja $\left(\mathrm{X}_{3}\right)$ & $\mathbf{0 . 8 8 5}$ & 0.159 & .694 & 5.580 & .000 \\
\hline
\end{tabular}

a. Konstanta $=3,337$, menunjukkan Kinerja Pegawai secara rataan yang tidak diperhitungkan dengan nilai konstan 3,337, akan tetapi untuk peubah Kinerja Pegawai memberikan pengaruh.

b. Koefisien $\beta_{1}=\mathbf{3 0} \%$, menunjukkan Keamanan Kerja memberikan pengaruh terhadap Kinerja Pegawai pada Kantor (OPD) Penanggulangan Bencana Kabupaten Majene Provinsi Sulawesi Barat.

c. Koefisien $\beta_{2}=43 \%$, menunjukkan Kesehatan Kerja memberikan pengaruh terhadap Kinerja Pegawai pada Kantor (OPD) Penanggulangan Bencana Kabupaten Majene Provinsi Sulawesi Barat.

d. Koefisien $\beta_{3}=\mathbf{8 8 \%}$, menunjukkan Keselamatan Kerja memberikan pengaruh terhadap Kinerja Pegawai pada Kantor OPD Penanggulangan Bencana Kabupaten Majene Provinsi Sulawesi Barat.

Berdasarkan uraian di atas, ketiga peubah tersebut didapatkan, Keselamatan Kerja mempunyai pengaruh terhadap Kinerja Pegawai di Kantor OPD Penanggulangan Kabupaten Majene Provinsi Sulawesi Barat yaitu 85\%, Hal ini di karenakan diperolah nilai koefisien lebih dominan dari Keamanan Kerja.

\section{KESIMPULAN}

Berdasarkan uraian dan hasil analisis, dapat disimpulkan hal berikut:

1. Keamanan kerja berpengaruh terhadap kinerja pegawai di Kantor OPD Penanggulangan Bencana Kabupaten Majene Provinsi Sulawesi Barat, dengan keamanan kerja dengan nilai $30 \%$.

2. Kesehatan kerja berpengaruh terhadap kinerja pegawai di Kantor OPD Penanggulangan Bencana Kabupaten Majene Provinsi Sulawesi Barat, dengan kesehatan kerja dengan nilai $43 \%$.
3. Keselamatan kerja lebih berpengaruh terhadap kinerja pegawai di Kantor OPD Penanggulangan Bencana Kabupaten Majene Provinsi Sulawesi Barat, di mana peubah keamanan kerja dengan nilai $88 \%$.

\section{DAFTAR PUSTAKA}

As'ad, M. 2001. Psikologi Industry - Seri Ilmu SDM. Penerbit: Liberty. Yogyakarta.

Daryanto, D. 2003. Keselamatan dan Kesehatan Kerja Bengkel. Jakarta: PT Bima Adiaksara dan PT Rineka Cipta.

Dharma, A, 2003. Manajemen Supervisi, Cetakan Kelima. Jakarta: PT Raja Grafindo Persada.

Ghozali, I. 2005. Aplikasi Analisis Multivariate dengan Program SPSS. Semarang: BP Universitas Diponegoro. Semarang.

Guritno, B dan Waridin. 2005. Pengaruh Persepsi Pegawai Mengenai Perilaku Kepemimpinan, Kepuasan Kerja Dan Motivasi Terhadap Kinerja. JRBI.Vol 1. (1). Hal: 63-74.

Hakim, A. 2006. Analisis Pengaruh Motivasi, Komitmen Organisasi dan Iklim Organisasi Terhadap Kinerja Pegawai Pada Dinas Perhubungan Dan Telekomunikasi Provinsi Jawa Tengah. JRBI. 2(2): 165-180.

Handoko, T. 2003. Manajemen Edisi 2. BPFE. Yogyakarta.

Hasibuan, M.S.P. 2001. Manajemen Sumber Daya Manusia. Jakarta: PT. Bumi Aksara.

Hasibuan, M. 2004. Manajemen Sumber Daya Manusia PT.Bumi Aksara.Jakarta.

Hasibuan, M. 2009. Manajemen Sumber Daya Manusia. Edisi Revisi. Jakarta: PT Bumi Aksara.

Husni, L. 2005. Hukum Ketenagakerjaan. Edisi Revisi. Jakarta: PT. Raja Grafindo

Mangkunegara, P.A. 2013. Manajemen sumber daya manusia Kantor. Bandung: PT Remaja Rosdakarya. 
Manullang. 2001. Manajemen Personalia. Yogyakarta: Gajah Mada University Press.

Nuraini, L. 2012. Kesehatan dan Keselamatan kerja bagi tenaga kesehatan.

Supranto, J. 2001. Statistik teori dan aplikasi. Edisi 6. Jakarta: Erlangga.
Swasto, B. 2011. Manajemen Sumber Daya Manusia. UB Press: Malang.

Wirawan. 2009. Evaluasi Kinerja Sumber Daya Manusia Teori Aplikasi dan Penelitian. Jakarta. Penerbit: Salemba Empat 